\title{
Induction of oxidative/nitrosative stress following Tc-99m pertechnetate thyroid scintigraphy in human
}

\section{İnsanda Tc-99m perteknetat tiroid sintigrafisini takiben oksidatif/nitrozatif stresin indüksiyonu}

\author{
Ebru Salmanoglu ${ }^{1}$, Ergull Belge Kurutas ${ }^{2}$
}

${ }^{1}$ Department of Nuclear Medicine, Kahramanmaras Sutcu Imam University, Faculty of Medicine, Kahramanmaras, Turkey ${ }^{2}$ Department of Medical Biochemistry, Kahramanmaras Sutcu Imam University, Faculty of Medicine, Kahramanmaras, Turkey

Corresponding author: Ebru Salmanoğlu, MD, Department of Nuclear Medicine, Kahramanmaras Sutcu Imam University, Faculty of Medicine, Kahramanmaras, Turkey

E-mail: ebrusalmanoglu@yahoo.com

Received/Accepted: November 21, 2018 /September 25, 2019

Conflict of interest: There is not a conflict of interest.

\section{SUMMARY}

Objective: Oxidative/nitrosative stress may be triggered by various sources, and ionizing radiation may also initiate oxidative/nitrosative stress.

This is the first study; we aimed to investigate the induction of oxidative and nitrosative stress due to ionizing radiation in patients undergoing Tc$99 \mathrm{~m}$ pertechnetate thyroid scintigraphy.

Method: Totally 26 patients (16 female, 10 male) undergoing Tc-99m pertechnetate thyroid scintigraphy were included in this study. The patients were aged between 20 and 50 years $(58.0 \pm 16.3$ years $)$. The blood samples were taken from patients 20 minutes after intravenous injection of Tc$99 \mathrm{~m}$ pertechnetate in the dose used clinically ( 5 miliCurie) before the patients were taken to the thyroid imaging. Control group was selected from 30 healthy subjects (15 female,15 male). The control group was aged between 17 and 72 years $(57.0 \pm 14.0$ years $)$. The blood samples were taken both patients and control group for measuring antioxidant enzymes (catalase and superoxide dismutase), malondialdehyde, nitric oxide, and nitrotyrosine as oxidative/nitrosative stress biomarkers.

Results: In this study, we found that activities of antioxidant enzymes increased in patients compared to control $(\mathrm{p}<0.05)$. Further, malondialdehyde levels as an indicator of oxidative stress were higher in patients than control group $(\mathrm{p}<0.05)$. The levels of nitric oxide and nitrotyrosine as nitrosative stress biomarkers also increased in patients compared to control groups $(\mathrm{p}<0.05)$.

Conclusions: We thought that Tc-99m pertechnetate might cause an increase in reactive oxygen and nitrogen species and may cause oxidative/nitrosative damage at the cellular level. Our results indicated that the dose of Tc-99m pertechnetate given in these patients undergoing thyroid scintigraphy could be tolerable.

Keywords: Radiation, nuclear medicine, oxidative and nitrosative stress, thyroid scintigraphy
(D) Ebru Salmanoglu

Ergul Belge Kurutas

ORCID IDs of the authors: E.S. 0000-0003-3183-4625 E.B.K. 0000-0002-6653-4801 
ÖZET

Amaç: Oksidatif ve nitrozatif stres çeşitli faktörler tarafından tetiklenebilir ve aynı zamanda iyonizan radyasyon da oksidatif ve nitrozatif stresi başlatabilir.

Bu ilk çalışmada, Tc-99m perteknetat tiroid sintigrafisi yapılan hastalarda iyonizan radyasyon nedeniyle indüklenen oksidatif ve nitrozatif stresi araştırmayı amaçladık.

Yöntem: Tc-99m perteknetat tiroid sintigrafisi yapılan toplam 26 hasta (16 kadın, 10 erkek) bu çalışmaya dahil edildi.

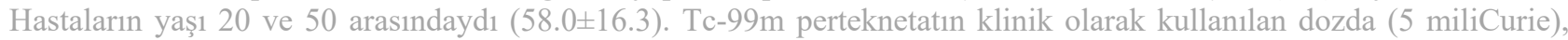
intravenöz enjeksiyonundan 20 dakika sonra, tiroid görüntülemeye alınmadan önce hastalardan kan örnekleri alındı.

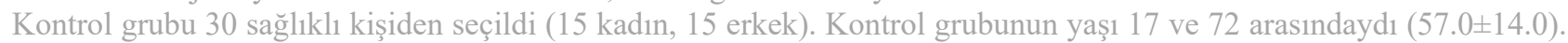
Antioksidan enzimlerin (katalaz ve superoksit dismutaz), oksidatif/nitrozatif stres biyomarkerları olarak malondialdehit, nitrik oksit ve nitrotirozinin ölçülmesi için hem hastalardan hem de kontrol grubundan kan örnekleri alındı.

Bulgular: Bu çalışmada antioksidan enzim aktivitesinin kontrol grubuna kıyasla hastalarda arttığını bulduk ( $<0.05)$. Ayrıca, oksidatif stres göstergesi olarak malondialdehit düzeyi hastalarda kontrol grubundan daha yüksekti $(\mathrm{p}<0.05)$. Aynı zamanda nitrozatif stres biyomarkerı olarak nitrik oksit ve nitrozamin düzeyleri kontrol grubuna kıyasla artmıştı $(\mathrm{p}<0.05)$.

Sonuç: Tc-99m perteknetat reaktif oksijen ve nitrojen türevlerinde artışa neden olabilir ve hücresel düzeyde oksidatif/nitrozatif hasara neden olabileceğini düşündük. Bu sonuçlar tiroid sintigrafisi yapılan hastalara verilen Tc-99m perteknetat dozunun tolere edilebileceğini gösterdi.

Anahtar sözcükler: Radyasyon, nükleer tıp, oksidatif ve nitrozatif stres, tiroid sintigrafisi

\section{INTRODUCTION}

Nuclear medicine is a multidisciplinary science branch in which radioactive substances are used in the diagnosis and treatment of diseases. The thyroid gland is an endocrine gland which is located in front of the neck. It is consist of the right lobe, left lobe and isthmus. The pyramidal lobe is seen at some people. The correct diagnosis is essential for the treatment of thyroid gland diseases. Thyroid scintigraphy is a nuclear medicine imaging method which is used for the diagnosis of thyroid gland diseases ${ }^{1,2}$.

In the respiration phase cells, a small amount of oxygen consumed is reduced, and this can lead to a production of highly chemical entities, called reactive oxygen and nitrogen species (ROS and RNS) that has been reported to have a dual role which brings beneficial and deleterious effects ${ }^{3}$. It was stated that in biological systems, the cellular functions focus on redox reaction which consists of oxidation or reduction of prooxidant and antioxidants. Oxygen-derived free radicals are the most reactive ROS and RNS which are electrochemically imbalance and quickly react with cells. If the balance of redox reaction is distorted, oxidative/nitrosative stress may occur, and lead to various pathological conditions ${ }^{4,5}$. Ionizing radiation may lead to ROS and RNS formation and results in damage either directly on the cells or indirectly affecting cellular DNA ${ }^{6}$. Linear Energy Transfer (LET) radiation may cause the generation of ROS and RNS that interact with biological molecules and producing toxic-free radicals $^{7}$. The final product of peroxidation is malondialdehyde (MDA), major aldehyde product that is mutagenic in cells and could be assessed to evaluate tissue injury. Ionizing-induced oxidative/nitrosative stress may increase MDA, subsequently being an interest for researchers. Human has defense mechanisms such as superoxide dismutase (SOD) and catalase (CAT) antioxidant enzymes against oxidative/nitrosative stress. SOD catalyzes the dismutation of the highly reactive superoxide anion to $\mathrm{O} 2$ and hydrogen peroxide $(\mathrm{H} 2 \mathrm{O} 2)$. In human, there are three forms of SOD; cytosolic SOD (CuZnSOD), mitochondrial SOD (MnSOD) and extracellular SOD. $\mathrm{Cu} / \mathrm{Zn}$-SOD is believed to play a significant role in the first line of the antioxidant defense system, and high SOD activities are correlated with high immune competence ${ }^{8}$. CAT is an enzyme virtually found in all aerobic cells that under certain conditions can play a critical role in detoxifying $\mathrm{H} 2 \mathrm{O} 2$; in tissues and is mainly localized in peroxisomes, but it may also be found in an unbound form in the cytoplasm ${ }^{9}$. Nitrotyrosine (3NTx) is a product of tyrosine nitration mediated by ROS such as peroxynitrite anion and nitrogen dioxide. 3-NTx is identified as an indicator or marker of nitrosative damage, inflammation as well as NO (nitric oxide) production. NO and NOdependent oxidants, such as peroxynitrite, are believed to play a role in the pathogenesis of various inflammatory diseases ${ }^{10}$.

To our knowledge, there is no study on Tc-99m pertechnetate (Tc-99m O4) on both oxidative and nitrosative stress in human. So, we aimed to investigate the oxidative and nitrosative stress due to ionizing radiation in patients undergoing Tc99m O4 thyroid scintigraphy. 


\section{MATERIAL AND METHODS}

\section{Ethics}

The study procedures were approved with the number 2016/12-09 by the local ethics committee. Prior to the initiation of the study, each subject was informed about the aim of the study and signed an informed consent form. The data collection of the study was performed over 6 months, June 2016 to November 2016.

\section{Study Population}

Patients ( $\mathrm{n}=26)$, (16 female,10 male) who were referred to the Department of Nuclear Medicine from various clinic departments for Tc-99m O4 thyroid scintigraphy were selected as the patient group. The patients were aged between 20 and 50 years $(58.0 \pm 16.3$ years). Informed consent forms were given all patients. The blood samples were taken from patients 20 minutes after intravenous injection of Tc-99m O4 in dose used clinically, 5 miliCurie $(\mathrm{mCi}) /$ patient, before the patients were taken to the thyroid imaging. Control group was selected from 30 healthy subjects ( 15 female, 15 male). The control group was aged between 17 and 72 years $(57.0 \pm 14.0)$.

\section{Oxidative/Nitrosative Stress Biomarkers's Measurements}

The blood samples were taken from 26 patients and 30 control individuals. Samples were centrifuged at $3000 \mathrm{~g}$ for 10 minutes at room temperature. Plasma was separated, and buffy coat was discarded by aspiration. Erythrocytes were washed 4 times with cold physiological saline and stored at $-70^{\circ} \mathrm{C}$ until analysis. The CAT activity in erythrocyte was measured in samples by method applied by Beutler ${ }^{11}$. The decomposition of the substrate $\mathrm{H} 2 \mathrm{O} 2$ was monitored spectrophotometrically at
$240 \mathrm{~nm}$. The activity of CAT was expressed as U/g $\mathrm{Hb}$. The SOD activities in erythrocyte were estimated by the use of the method described by Fridovich $^{12}$. The SOD activity was expressed as $\mathrm{U} / \mathrm{g} \mathrm{Hb}$. Lipid peroxidation level in the plasma samples was shown in MDA. Measurement was based on the method of Ohkawa ${ }^{13}$. MDA levels were expressed as $\mathrm{nmol} / \mathrm{mL}$. NO concentration in plasma samples was measured using the Griess reaction ${ }^{14}$. NO levels were expressed as $\mu \mathrm{mol} / \mathrm{L}$. Also, 3-NTx levels in plasma samples were determined with a "sandwich" enzyme-linked immunosorbent assay kit (Bioxytech Nitrotyrosine-EIA; Oxis-Research, Portland, OR) according to the manufacturers' protocol. Then, 3NTx levels were given as nmol/L.

\section{Statistical Analysis}

Statistical analysis was carried out using SPSS 15.0 for Windows statistical software. The conformability of the quantitative data to the normal distribution was examined by the Kolmogorov-Smirnov test. The Mann-Whitney U-test was used to compare mean values for all parameters between patients and control groups. $p$ $<0.05$ was considered statistically significant.

\section{RESULTS}

The activities of antioxidant enzymes (CAT, SOD) were increased in the patients' group compared to the control group $(p<0.05)$ as shown in Figure 1a, 1b. CAT and SOD activities were increased about 1.5 and 1.6-fold, respectively. Furthermore, MDA levels were increased about two-fold as shown in Figure 1c, and 3NTx levels were about three times as shown in Figure 2a,2b, due to Tc-99m O4 induced oxidative/nitrosative damage in the patient group. 


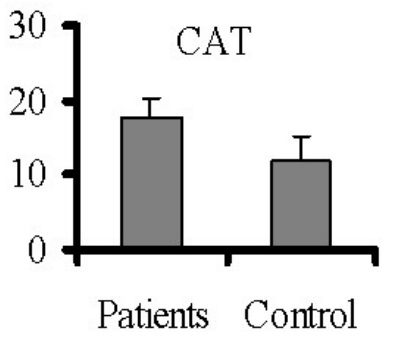

(a)

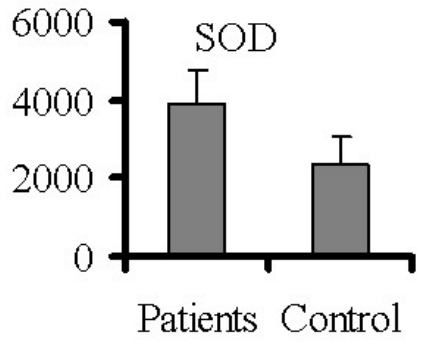

(b)

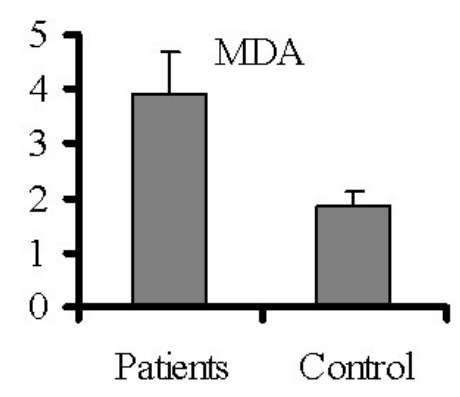

(c)

Figure 1: The activities of catalase (CAT) (a), superoxide dismutase (SOD) (b) and malondialdehyde (MDA) (c) levels as oxidative stress biomarkers in patients and control group.

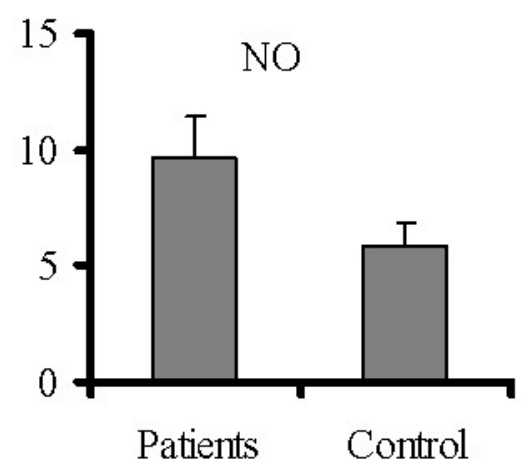

(a)

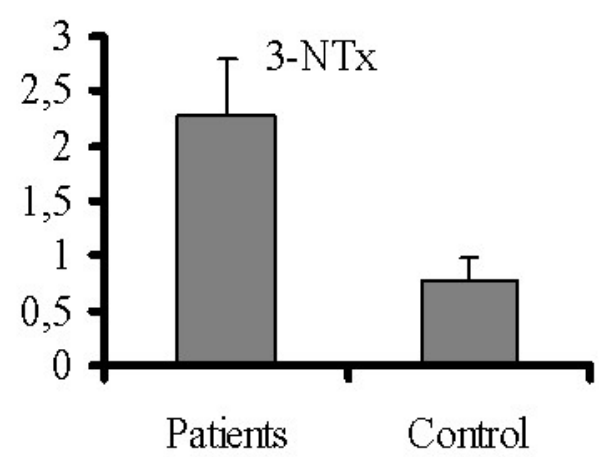

(b)

Figure 2: The activities of nitric oxide (NO) (a), nitrotyrosine (3-NTx) (b) levels as nitrosative stress biomarkers in patients and control group.

\section{DISCUSSION}

Ionizing radiation is classified as a potent carcinogen which causes several effects depending on exposure and absorption dose, duration of exposure, and interval after exposure and susceptibility of tissues to ionizing radiation ${ }^{15}$. Thyroid scintigraphy has a vital role in the diagnosis of thyroid gland diseases. Various radioactive substances such as radioiodine-131 (131I), radioiodine-123 (123I), and Tc-99m O4 are used for thyroid scintigraphy. 131I and 123I taken to thyroid cells via sodium-iodide symporter (NIS) and uses trapping and organification mechanism. Tc-99m O4 is taken up in cells in the thyroid gland, but it doesn't enter the organification process such as radioactive iodine. The radiation dose which is given to the patient with Tc-99m O4 is lower than the radioactive iodine. Due to the weak radiation dose, Tc-99m O4 is preferred. Tc- $99 \mathrm{~m} \mathrm{O} 4$ is a radionuclide which is reliable, easily accessible, widely used in clinical nuclear medicine applications ${ }^{16-25}$. 
Induction of oxidative and nitrosative stress pathways is the critical phenomenon for various diseases: intracellular inflammation, with increased production of nuclear factor kappa beta (NFkappabeta), cyclo-oxygenase-2 (COX-2) and inducible NO synthase (iNOS); and damage caused by oxidative and nitrosative stress to membrane fatty acids and functional proteins. These oxidative and nitrosative stress pathways are induced by a number of trigger factors, for example, psychological stress, strenuous exercise, viral infections, radiation, etc. Shahin et al. reported that the effect of short and long-term low-level microwave (MW) radiation exposure on hippocampus in mice. They found that exposure to MW radiation causes increased free radical load and it stimulates cellular oxidative/nitrosative stress, reduce the antioxidant defense system in hippocampus. It caused p53dependent/independent activation of hippocampal neuronal and nonneuronal apoptosis through the oxidative damage of cellular components such as proteins, lipids, and nucleic acids. It caused spatial memory $\operatorname{loss}^{26}$. In another study, the protective role of SODs against ionizing radiation was investigated in the wild-type and in mutant yeast strains lacking CuZnSOD, MnSOD or both SODs. Mutants deleted for SOD genes were more sensitive to ionizing radiation than wild-type cells. Activities of antioxidant enzymes, such as CAT, glutathione reductase, and glucose 6-phosphate dehydrogenase, were increased in both wild-type and mutant cells upon exposure to ionizing radiation. So, both $\mathrm{CuZnSOD}$ and MnSOD may play a central role in protecting cells against ionizing radiation through the removal of ROS, as well as in the protection of antioxidant enzymes ${ }^{27}$.

This is the first study; we found that the activities of antioxidant enzymes (CAT, SOD) in the blood of patients were significantly increased compared to the control group. This may possibly due to low dose the damaging action of ionizing radiation. Also, we thought that after Tc-99m O4 thyroid scintigraphy, cells might increase the antioxidant response and overcome stress. However, after serious oxidative damage, if the duration and dose of Tc-99m O4 for thyroid scintigraphy were applied as high, cells would be no longer able to protect themselves, and even antioxidant enzymes could be degraded.

MDA is the most frequently used biomarker of oxidative stress in many health problems such as cancer, psychiatry, chronic obstructive pulmonary disease, asthma, or cardiovascular diseases ${ }^{4,5}$. In the present study, the level of MDA in patients showed significant increment compared with the control group, and this may indicate the occurrence of oxidative damage induced by ionizing radiation. Tc-99m O4 may destruct lipid portion of cells and leads to high MDA concentration in patients. In our study, MDA levels were also increased about twofold in patients undergoing Tc-99m O4 thyroid scintigraphy. We thought that increased MDA levels might cause the induction of oxidative stress. This is in agreement with previous studies which stated that lipid peroxidation might disrupt biological membranes and damaged membrane's structure4,5. A study by Van Ginkel and Sevanian reported that MDA itself has shown to cause extreme alterations in structural and functional of layers. Authors reported results of some studies on oxidative stress the effects of ionizing radiation in rats $^{28}$. For example, in a study whole-body, gamma irradiation of rats at $8 \mathrm{~Gy}$ was evaluated. It was reported that, exposure to ionizing radiation caused meaningful increase in the levels of MDA, glutamic oxaloacetic transaminase (ALT), glutamic aspartate transaminase (AST), alkaline phosphatase (ALP) and gamma-glutamyl transferase (GGT) activities and concentration of total cholesterol (TC), triglyceride (TG) and lowdensity lipoprotein cholesterol (LDL-C), however caused significant decrease glutathione content (GSH), SOD, CAT, and GPx activities and highdensity lipoprotein cholesterol (HDL-C) concentration in rats ${ }^{29}$.

The free radical gas NO performs many useful functions when produced in vivo, e.g., by neurons and endothelial cells. However, excess NO can exert cytotoxic and cytostatic effects 4,5. Our results showed that $\mathrm{NO}$ level increased in patients undergoing Tc-99m O4 thyroid scintigraphy. Although harmful effects of NO might be mediated by a number of diverse mechanisms, it is commonly assumed that such actions are mainly due to the generation of reactive by-products generated during the oxidative metabolism of NO; these are collectively termed RNS. One of the prime suspects commonly implicated in the adverse or harmful properties of NO is peroxynitrite, a potent oxidative species formed by its almost diffusion-limited reaction with superoxide radicals, which is a product of activated phagocytes and of endothelial or epithelial cells. The formation of peroxynitrite seems highly feasible under conditions of elevated production of both $\mathrm{NO}$ and superoxide radicals in vivo, and its oxidative and cytotoxic potential is well documented ${ }^{30}$. The formation of 3-NTx is regarded as a marker of nitrosative stress and is observed in inflammatory processes under excess production of NO and oxidants. 3-NTx containing proteins have 
been described in different human and animal diseases. The analyses presented here are highly indicative of the presence of 3-NTx in serum samples of patients undergoing Tc-99m O4 thyroid scintigraphy. Our data provided that NO may be a mediator of nitrosative damage in serum samples of patients undergoing Tc-99m pertechnetate thyroid scintigraphy.

\section{CONCLUSION}

Intravenous injection of Tc-99m O4 results in an increase of both oxidative and nitrosative stress. Also, antioxidant defense of the patients was higher compared to healthy subjects possibly due to an adaptive response to ionizing radiation in the living cells and thereby protected the cells against oxidative damage. It shows that living cells can tolerate ionizing radiation. Concerning the importance of assessing the induction of oxidative/nitrosative stress following ionizing radiation, further research should be done in-depth.

\section{REFERENCES}

1. Harjeet A, Sahni D, Jit I, Aggarwal AK. Shape, measurements, and weight of the thyroid gland in northwest Indians. Surg Radiol Anat. 2004;26:915.

2. Smith JR, Oates E. Radionuclide imaging of the thyroid gland: patterns, pearls, and pitfalls. Clin Nucl Med. 2004;29:181-193.

3. Valko M, Leibfritz D, Moncol J, Cronin MT, Mazur M, Telser J. Free radicals and antioxidants in normal physiological functions and human disease. Int J Biochem Cell Biol. 2007;39:44-84.

4. Kurutas EB. The importance of antioxidants which play a role in cellular response against oxidative/nitrosative stress: current state. Nutr J. 2016;15:71.

5. Kurutas EB, Ozturk P. The evaluation of local oxidative/nitrosative stress in patients with pityriasis versicolor: a preliminary study. Mycoses. 2016;59:720-725.

6. Georgieva S, Popov B, Bonev G. Radioprotective effect of Haberlea rhodopensis (Friv.) leaf extract on gamma-radiation-induced DNA damage, lipid peroxidation and antioxidant levels in rabbit blood. Indian $\mathrm{J}$ Exp Biol. 2013;5129-36.

7. Azab KS, Bashandy M, Salem M, Ahmed O, Tawfik Z, Helal H. Royal jelly modulates oxidative stress and tissue injury in gamma irradiated male Wister Albino rats. N Am J Med Sci. 2011;3:26876.
8. Georgeson GD, Szony BJ, Streitman K, Varga IS, Kovács A, Kovács L, et al. Antioxidant enzyme activities are decreased in preterm infants and in neonates born via cesarean section. Eur J Obstet Gynecol Reprod Biol. 2002;103:136-9.

9. Akman SA, Forrest G, Chu FF, Doroshow JH. Resistance to hydrogen peroxide associated with altered catalase mRNA stability in MCF7 breast cancer cells. Biochim Biophys Acta. 1989;1009:70-4.

10. Beckman JS, Crow JP. Pathological implications of nitric oxide, superoxide and peroxynitrite formation. Biochem Soc Trans. 1993;21:330-4.

11. Beutler E. Red Cell Metabolism. A Manual of Biochemical Methods. 2nd ed. New York: Grune and Stratton Inc; 1984. p. 68-70.

12. Fridovich I. Superoxide dismutase. Adv Enzymol 1974;41:35-97.

13. Ohkawa H, Ohishi N, Yagi K. Assay for lipid peroxides in animal tissues by the thiobarbituric acid reaction. Anal Biochem. 1979;95:351-8.

14. Cortas NK, Wakid NW. Determination of inorganic nitrate in serum and urine by a kinetic cadmium-reduction method. Clin Chem. 1990;36:1440-3.

15. Karbownik M, Reiter RJ. Antioxidative effects of melatonin in protection against cellular damage caused by ionizing radiation. Proc Soc Exp Biol Med. 2000;225:9-22.

16. Daniels GH. Radioactive iodine: a slice of history. Thyroid. 2013;23:253-258.

17. Wong KK, Gandhi A, Viglianti BL, Fig LM, Rubello D, Gross MD. Endocrine radionuclide scintigraphy with fusion single photon emission computed tomography/computed tomography. World J Radiol. 2016;8:635-55.

18. Sarkar SD. Benign thyroid disease: what is the role of nuclear medicine? Semin Nucl Med. 2006;36:185-93.

19. Intenzo CM, dePapp AE, Jabbour S, Miller JL, Kim SM, Capuzzi DM. Scintigraphic manifestations of thyrotoxicosis. Radiographics. 2003;23: 857-69.

20. Wong KK, Fig LM, Youssef E, Ferretti A, Rubello D, Gross MD. Endocrine scintigraphy with hybrid SPECT/CT. Endocr Rev. 2014;35:717-46.

21. Subramanyam P, Palaniswamy SS. Pictorial essay of developmental thyroid anomalies 
identified by Technetium thyroid scintigraphy. Indian J Nucl Med. 2015 ;30:323-7.

22. Leslie WD, Dupont JO, Bybel B, Riese KT. Parathyroid 99mTc-sestamibi scintigraphy: dualtracer subtraction is superior to double-phase washout. Eur $\mathrm{J}$ Nucl Med Mol Imaging. 2002;29:1566-70.

23. Lin DS. Thyroid imaging - mediastinal uptake in thyroid imaging. Semin Nucl Med. 1983;13:3956.

24. Schoen EJ, Clapp W, To TT, Fireman BH. The key role of newborn thyroid scintigraphy with isotopic iodide (123I) in defining and managing congenital hypothyroidism. Pediatrics. 2004;114:e683- 688.

25. Ruchala M, Szczepanek E, Sowinski J. Diagnostic value of radionuclide scanning and ultrasonography in thyroid developmental anomaly imaging. Nucl Med Rev Cent East Eur. 2011;14:21-8.

26. Shahin S, Banerjee S, Singh SP, Chaturvedi CM. $2.45 \mathrm{GHz}$ Microwave radiation impairs learning and spatial memory oxidative/nitrosative stress induced p53-dependent/independent hippocampal apoptosis: molecular basis and underlying mechanism. Toxicol Sci. 2015;148:380-99.
27. Lee JH, Choi IY, Kil IS, Kim SY, Yang ES, Park JW. Protective role of superoxide dismutases against ionizing radiation in yeast. Biochim Biophys Acta. 2001;1526:191-8.

28. van Ginkel G, Sevanian A. Lipid peroxidationinduced membrane structural alterations. In L. P. B. T.-M. in Enzymology (Ed.), 1994; Oxygen Radicals in Biological Systems Part C (Vol. 233: 273-288). Academic Pres.

29. Abdel-Shafi S, Saad TMM, MEF AbdelHaliem, Ghonemey ARMA, Enan G. Radioprotective Role of Some Bacteria Belonging to Actinomycetales against Gamma IrradiationInduced Oxidative Stress in Male Albino Rats. Egypt J H Med. 2016;64:364- 372.

30. Beckman JS, Koppenol WH. Nitric oxide, superoxide, and peroxynitrite: the good, the bad, and the ugly. Am J Physiol. 1996;271:C1424C1437. 